University of Nebraska - Lincoln

DigitalCommons@University of Nebraska - Lincoln

Agronomy \& Horticulture -- Faculty Publications

Agronomy and Horticulture Department

2008

\title{
Importance and Effect of Nitrogen on Crop Quality and Health
}

\author{
Jürg Blumenthal \\ University of Nebraska-Lincoln \\ David D. Baltensperger \\ University of Nebraska-Lincoln, dbaltensperger@tamu.edu \\ Kenneth G. Cassman \\ University of Nebraska-Lincoln, kcassman1@unl.edu \\ Stephen Mason \\ University of Nebraska-Lincoln, smason1@unl.edu \\ Alexander Pavlista \\ University of Nebraska-Lincoln, apavlista@unl.edu
}

Follow this and additional works at: https://digitalcommons.unl.edu/agronomyfacpub

Part of the Plant Sciences Commons

Blumenthal, Jürg; Baltensperger, David D.; Cassman, Kenneth G.; Mason, Stephen; and Pavlista, Alexander, "Importance and Effect of Nitrogen on Crop Quality and Health" (2008). Agronomy \& Horticulture -- Faculty Publications. 200.

https://digitalcommons.unl.edu/agronomyfacpub/200

This Article is brought to you for free and open access by the Agronomy and Horticulture Department at DigitalCommons@University of Nebraska - Lincoln. It has been accepted for inclusion in Agronomy \& Horticulture -Faculty Publications by an authorized administrator of DigitalCommons@University of Nebraska - Lincoln. 


\title{
Importance and Effect of Nitrogen on Crop Quality and Health
}

\author{
Jürg M. Blumenthal, ${ }^{1}$ David D. Baltensperger, ${ }^{1}$ Kenneth G. Cassman, ${ }^{2}$ \\ Stephen C. Mason, ${ }^{2}$ and Alexander D. Pavlista ${ }^{1}$ \\ ${ }^{1}$ Panhandle Research \& Extension Center, University of Nebraska, \\ Scottsbluff, NE, USA \\ ${ }^{2}$ Department of Agronomy and Horticulture, University of Nebraska-Lincoln, \\ Lincoln, NE, USA
}

\begin{abstract}
Nitrogen $(\mathrm{N})$ is often the most limiting factor in crop production. Hence, application of fertilizer nitrogen results in higher biomass yields and protein yield and concentration in plant tissue is commonly increased. Nitrogen often affects amino acid composition of protein and in turn its nutritional quality. In cereals, abundant supply of nitrogen decreases the relative proportion of lysine and threonine, thus, reducing the biological value of the protein. Increasing nitrogen supply generally improves kernel integrity and strength, resulting in better milling properties of the grain. In oil seed crops, protein levels are increased upon nitrogen fertilization, whereas oil concentration is decreased. Effects of nitrogen fertilization on oil composition and quality are inconsistent. In sugarbeet production, abundant supply of nitrogen results in a reduction of sucrose concentration per unit fresh matter and to an increase in impurities (alpha-amino-nitrogen, invert sugars, and lime salts), which negatively affect efficiency of sucrose extraction. Nitrogen supply to potatoes primarily influences tuber size, dry matter, and sugar contents. Nitrogen supply is managed according to market classes (table stock, French fries, and potato chips), which require different quality parameters.
\end{abstract}

\section{Cereals}

\subsection{Corn}

Corn (Zea mays L.) is the third most important crop worldwide following rice (Oryza sativa L.) and wheat (Triticum aestivum L.). The corn kernel is composed of approximately $72 \%$ starch, $10 \%$ protein, $5 \%$ oil, $2 \%$ sugar, and $1 \%$ ash with the remainder being water (Perry, 1988). The corn protein biological value is low due to the low concentration of the essential amino acids, lysine and tryptophan, although opaque- 2 corn has been developed with higher levels of these two amino acids (Mertz et al., 1964). Recent breeding efforts by CYMMYT have improved the hardness of opaque-2 corn cultivars (Vasal et 
al., 1980), thus improving the agronomic characteristics of this corn type. The oil in corn is an important energy source for livestock feed, and due to a high degree of unsaturation, is widely used for human consumption (Perry, 1988). Increasing nitrogen supply to corn generally resulted in increased grain and protein yields and increased grain protein concentration (Olsen et al., 1976; Pierre et al., 1977; Cromwell et al., 1983; Tsai et al., 1983; Anderson et al., 1984; Kniep and Mason, 1991; Sabata \& Mason, 1992; Tsai et al., 1992; Oikeh et al., 1998). Research reported by Tsai et al. (1983) suggested that protein concentration of corn grain increases with nitrogen supply due to preferential deposition of zein over the other endosperm proteins. It is apparent that the amount of fertilizer nitrogen required to maximize grain yields is not the same as the amount that will produce maximum grain protein concentrations (Sander et al., 1987). As the protein concentration of corn grain increases, zein makes up an increasing proportion of the protein (Frey et al., 1949; Frey, 1951; Tsai et al., 1992). Rendig and Broadbent (1977) reported that concentration of the protein fraction zein in corn grain was closely associated with the level of soil nitrogen, with each added increment of nitrogen increasing the percentage of zein. Tsai et al. (1983) reported that as nitrogen levels increased, zein accumulated preferentially in normal corn grain, but not in grain of opaque2 hybrids. Tsai et al. (1992) reported that protein yield increase from nitrogen application was accompanied by an increase in the amount of zein present in the endosperm, creating harder, less brittle and more translucent grain. Since zein contains lower amounts of the most limiting essential amino acids, lysine and tryptophan, increased grain yields change the amino acid balance by reducing the lysine and tryptophan concentrations, thus reducing the biological value of the grain protein. However, this may be compensated for in some cases since nitrogen fertilizer application increases the size of the germ, which has a better amino acid balance than the endosperm (Bhatia and Rabson, 1987). In contrast, studies with opaque-2 corn hybrids indicate that increased nitrogen supply maintains or increases the lysine concentration of grain (Cromwell et al., 1983; Tsai et al., 1983).

Kniep and Mason (1991) found that irrigation increased grain yield, reduced protein concentration, had no effect on percent lysine per sample, and increased percent lysine of protein of normal corn. Nitrogen application increased grain yield, protein concentration and percent lysine of sample, but decreased percent lysine of protein. Irrigation decreased percent lysine per sample for opaque-2 hybrids. The grain from the above study was used in a rat feeding experiment, and found that rats fed grain produced with irrigation had greater and more efficient rates of gain, while those fed grain from plots with nitrogen application had lower and less efficient rates of gain (Hancock et al., 1988). These studies, and the one previously reported by Bullock et al. (1989), clearly indicate that irrigation increases grain and protein yields, and lowers protein concentration, but improves the biological value of the protein. In contrast, nitrogen application increases grain and protein yields, and protein concentration, but reduces the biological value of the protein. Similar results for nitrogen fertilizer application, except the adverse effect of nitrogen fertil- 
izer application on percent lysine and tryptophan was less for opaque-2 hybrids than for normal hybrids were reported by Breteler (1976). MacGregor et al. (1961) found that amino acid concentrations of grain did not increase uniformly to nitrogen fertilizer application, and that the concentrations of lysine, methionine, and phenylalanine did not increase. Rendig and Broadbent (1979) found that nitrogen fertilizer application decreased the concentrations of tryptophan, lysine, glycine, arginine, and threonine in protein, while concentrations of alanine, phenylalanine, tyrosine, glutamic acid, and leucine were increased. It is apparent that irrigation has a positive effect on corn grain amino acid balance, while nitrogen fertilizer application has a negative effect.

Large uniform kernel size is desired for dry milling (Paulsen \& Hill, 1985), wet milling (Watson, 1987), alkaline cooked products (Shumway et al., 1992), and livestock feed when processed by rolling or cracking. Most agronomic studies have focused on kernel weight which often is highly associated with both kernel density and/or size (Watson, 1987). Personal communications from livestock feeders and dry millers indicate that uniformity of kernel size is important, but has not been studied scientifically. Kernel weight has been shown to increase with increasing nitrogen application (Rendig and Broadbent, 1979; Cromwell et al., 1983; Bauer and Carter, 1986; Kniep and Mason, 1989).

Physical quality of grain is usually measured by kernel hardness (density), kernel breakage susceptibility (brittleness), and stress cracking. Physical quality is a primary concern of the corn dry milling industry to optimize the production of the highest value end-product of uniform, large flaking grits (Paulsen and Hill, 1985). Bauer and Carter (1986) and Kniep and Mason (1989) found that kernel breakage decreased and kernel density increased with nitrogen fertilizer application.

There are few studies on agronomic practice influencing the oil concentration of corn grain, although the development of the specialty high-oil corn for livestock feed (Alexander, 1988) has spurred much recent interest. Earle (1977) showed variations in oil concentration by year from 1917 to 1972, but no correlations were found between oil concentration and variations in temperature, rainfall, or fertilization. Welch (1969) reported that nitrogen, phosphorus, and potassium applications increased the oil concentration of corn grain slightly, but more important was that the increased grain yield resulted in greater oil production per unit of land area. In contrast, Jellum et al. (1973) found that increasing nitrogen application rate had no influence on the oil concentration of corn grain.

\subsection{Wheat}

Wheat is grown across a wide range of environments around the world. A broad range of food products stem from wheat. The protein of wheat is unique among cereals. The glutein protein fraction of wheat can trap and retain $\mathrm{CO}_{2}$ generated during the fermentation of dough. The most common products are leavened and unleavened baked bread. Other important wheat products are pastries, crackers, biscuits, and pasta. Production factors that increase grain yield also increase the starch concentration of grain while reduc- 
ing the grain protein concentration (McDermitt and Loomis, 1981). This inverse relationship has been shown in barley (Hordeum vulgare L.), corn, oats (Avena sativa L.), rice, sorghum (Sorghum bicolor (L.) Moench), and wheat (Prey, 1977). The negative relationship between protein concentration and grain yield is partly associated with the higher glucose costs for synthesis of protein than carbohydrates (Penning de Vries et al., 1974); thus the higher cost of protein synthesis is logically inversely related to the grain yield (Bhatia and Rabson, 1976).

Benzian and Lane (1979) analyzed the relationship between nitrogen supply, grain yield, and grain protein concentration for wheat. They found that a greater nitrogen supply increased grain protein concentration linearly while grain yield response to added nitrogen had a diminishing return relationship. They also found that when nitrogen was very limiting, small nitrogen additions resulted in greater grain yield with decreased protein concentration caused by dilution of the plant nitrogen. However, at higher levels of nitrogen, which are far more common, grain and protein yields usually increased while the grain protein concentration increased as well.

Goos et al. (1982) determined protein threshold values of $120 \mathrm{~g}$ protein per kilogram of grain for winter wheat and later $140 \mathrm{~g}$ protein per kilogram of grain in spring wheat (Goos, 1984). If wheat protein concentration was below these threshold values, the yield of the crop was limited by nitrogen. Higher protein concentrations than the threshold values could be obtained by increasing nitrogen fertilization. At this level of fertilization, however, only protein concentration increased, whereas no significant effects on crop yield were observed (Christensen and Killhorn, 1981; Fowler and de la Roche, 1984). Foliar applications of nitrogen and fertilization late in the growing season tended to have a greater effect on increasing grain protein concentration than on increasing grain yield (Altman et al., 1983; Gallagher et al., 1973).

Wheat protein is high in glutamic acid and proline, whereas lysine, threonine, methionine, and cystine concentrations are lower than those recommended by the World Health Organization (WHO) (Simmonds, 1978). Kies and Fox (1974) determined that lysine was the most limiting amino acid for human nutrition in wheat protein. The composition of amino acids in wheat protein is affected by nitrogen fertilization. Poulsson (1973) and Timms et al. (1981) found that nitrogen fertilization increased the proportion of glutamine, proline, and phenylalanine in wheat protein, while threonine, serine, glycine, alanine, valine, and sulfur amino acids decreased. The balance between nitrogen and sulfur nutrition of the wheat crop also had an effect on grain amino acid composition. Byers and Bolton (1979) and Wrigley et al. (1980) observed that high levels of nitrogen supply and marginal levels of sulfur supply resulted in marked reductions of the concentration of cysteine and methionine. Timms et al. (1981) observed the similar reductions caused by a nitrogento-sulfur imbalance induced by late-season fertilization of wheat with urea. These changes in amino acid composition affected the quality of the gluten. 
Timms et al. (1981) found in their study that bread baked with flour containing the highest protein concentration had a lower loaf volume and a lower texture score.

Almost $80 \%$ of the kernel protein is found in the endosperm (Vogel et al., 1976). Eighty-five percent of the protein in the endosperm is storage protein. The gliandin (alcohol soluble) fraction and the glutenin (alkali or acid soluble) fraction are the two forms of storage protein. When protein increases in a given cultivar, the gliandin fraction increases, while the glutenin fraction decreases (Ulmer, 1973). Shorter baking mixing times due to this shift in storage protein composition are a consequence of increasing protein levels in wheat (Finney et al., 1987). In a study conducted in Nebraska, Blumenthal et al. (2000) found that increased levels of protein caused by nitrogen fertilization resulted in shorter baking mixing times of flour of 12 different winter wheat varieties (Table 1).

\subsection{Rice}

Rice is the primary source of dietary energy and protein for nearly three billion people in Asia. Head rice is more valuable than brokens, and consumers prefer translucent, white grains. Nitrogen nutrition has a large influence on rice grain quality through effects on milling characteristics, translucence, and color.

Most rice is consumed as "white rice." White rice is obtained after dehulling the rough rice, as harvested from the field, to produce brown rice, which undergoes abrasive milling to remove the outer layers of pericarp, seed coat and nucellus, the germ or embryo, and aleurone layers (Juliano, 1993). After milling, white rice represents about $70 \%$ of the original yield of rough rice.

Table 1. Effect of fertilizer nitrogen on grain protein and dough mixing time (mixograph) of winter wheat.

\begin{tabular}{|c|c|c|}
\hline $\begin{array}{l}\text { Nitrogen fertilizer } \\
\text { treatment* (kg N/ha) }\end{array}$ & $\begin{array}{l}\text { Grain protein } \\
\text { concentration }(\mathrm{g} / \mathrm{kg})\end{array}$ & $\begin{array}{l}\text { Time to peak } \\
\text { resistance (min) }\end{array}$ \\
\hline 0 & $104^{* *}$ & $4.73^{* *}$ \\
\hline 15 & 107 & 4.64 \\
\hline 30 & 110 & 4.44 \\
\hline 45 & 113 & 4.39 \\
\hline 60 & 117 & 4.23 \\
\hline 75 & 121 & 4.11 \\
\hline $\mathrm{LSD}_{0.05}$ & 4 & 0.21 \\
\hline
\end{tabular}

Adapted from Blumenthal et al. (2000).

* Fertilizer treatments were ammonium nitrate applied topdress in early spring.

** Values are means of 12 winter wheat varieties, 4 years, and 4 locations each year. 
Crop nitrogen supply and plant nitrogen status have a marked effect on final protein content of both the brown and white rice. Early work with improved rice varieties conducted in the 1960s and 1970s demonstrated that grain protein could be significantly increased by ensuring adequate nitrogen fertilizer application up to panicle initiation stage (Nangju and De Datta, 1970; De Datta et al., 1972). Subsequent field research has found that improved fertilizer nitrogen use efficiency to achieve both high yields and high grain quality requires careful attention to the rate and timing of nitrogen fertilizer applications such that the total available nitrogen supply from soil and fertilizer is congruent with crop nitrogen demand. In high-yield production systems, improved congruence between nitrogen supply and crop demand sometimes requires several split applications - including a final nitrogen topdressing at flowering stage (Perez et al., 1996). In one field study with transplanted rice in the Philippines, an additional nitrogen topdressing at flowering resulted in a $6 \%$ increase in rough rice yield and a $25 \%$ increase in grain protein compared to a treatment that received all of the nitrogen fertilizer by panicle initiation stage (Table 2). Although the rate and timing nitrogen treatments are confounded in this study, additional studies have consistently demonstrated the effectiveness of nitrogen application at flowering to optimize both yield and grain protein in high yield systems where soil nitrogen is not sufficient to meet crop nitrogen demand during grainfilling.

An increase in rice grain protein is primarily reflected in greater amounts of the storage proteins glutelin and prolamin (Cagampang et al., 1966). These proteins are located in protein bodies within the starchy endosperm. When total grain protein is less than $10 \%$, an increase in grain protein causes little reduction in lysine content. Most commercial rice has grain protein below $10 \%$. Therefore, protein quality should not be significantly reduced when nitrogen management increases grain protein up to this $10 \%$ threshold.

Table 2. Effect of rate and timing of nitrogen fertilizer application on rice yield and quality characteristics.

\begin{tabular}{|c|c|c|c|c|c|c|c|c|c|}
\hline \multicolumn{5}{|c|}{$\begin{array}{l}\text { Nitrogen fertilizer } \\
\text { treatment* (kg/ha) }\end{array}$} & \multirow{2}{*}{$\begin{array}{l}\text { Rough } \\
\text { Rice } \\
\text { Yield } \\
\text { (kg/ha) }\end{array}$} & \multirow{2}{*}{$\begin{array}{l}\text { Head } \\
\text { rice } \\
(\%) \\
\end{array}$} & \multirow{2}{*}{$\begin{array}{l}\text { Head } \\
\text { Rice } \\
\text { Yield } \\
(\mathrm{kg} / \mathrm{ha})\end{array}$} & \multirow{2}{*}{$\begin{array}{l}\text { Protein } \\
(\%)\end{array}$} & \multirow{2}{*}{$\begin{array}{l}\text { Translucency } \\
(\%)\end{array}$} \\
\hline PP & MT & PI & PL & Total & & & & & \\
\hline 0 & 0 & 0 & 0 & 0 & $5.3 c$ & $37.5 c$ & $2.0 \mathrm{c}$ & $5.6 \mathrm{c}$ & $58.2 \mathrm{c}$ \\
\hline 120 & 0 & 60 & 0 & 180 & $9.3 b$ & $47.1 b$ & $4.4 \mathrm{~b}$ & $7.6 \mathrm{~b}$ & $76.4 b$ \\
\hline 60 & 60 & 60 & 45 & 225 & $9.9 \mathrm{a}$ & $57.7 \mathrm{a}$ & $5.7 \mathrm{a}$ & $9.6 a$ & $85.5 a$ \\
\hline
\end{tabular}

Modified from Perez et al. (1996).

Means in the same column followed by different letters are statistically different at $P<0.001$ by Ducan's multiple range test.

* Nitrogen fertilizer timing designations: PP, preplant; MT, maximum tillering; PI, panicle initiation; FL, flowering. 
The influence of nitrogen management on rice milling properties is as important as the effects of plant nitrogen nutrition on grain protein. Increased grain protein makes brown rice more resistant to cracking and breakage during abrasive milling than low protein rice of the same variety. Typically there is a tight, positive correlation between grain protein content and head rice yield. For example, in the previously cited study, head rice percentage was $58 \%$ of the rough rice for high-protein rice that was obtained when nitrogen fertilizer was applied at flowering versus only $47 \%$ head rice when the last nitrogen topdressing was applied at panicle initiation (Table 2). Taken together with the $6 \%$ increase in yield of rough rice, with a nitrogen application at flowering, head rice yield increased by $30 \%$ and head rice protein yield increased by $63 \%$ compared to the treatment without nitrogen application after panicle initiation.

Grain protein also has a large impact on other quality traits. Translucency is often positively correlated with protein content of milled rice, while grain whiteness can decrease as grain protein increases (Cagampang et al., 1966). Through appropriate nitrogen fertilizer management, however, it is possible to increase protein content and translucency while maintaining whiteness within acceptable limits. Such was the case in the Perez et al. (1996) study in which translucency increased from $76.4 \%$ to $85.5 \%$ with a nitrogen application at flowering stage (Table 2), while whiteness remained above $40 \%$ (data not shown), which is comparable to milled rice whiteness in most Asian and European markets. Although grain protein content also affects other quality traits related to palatability, such as stickiness and chewiness (Hamaker, 1994), preferences for these traits vary widely in different regions and countries.

\section{Oil Seed Crops}

Oil seed crops are recognized as those whose oil is the most valuable component of the seed, being utilized for both edible and industrial purposes. There is also considerable vegetable oil produced as a byproduct of extraction for other components as is the case with corn oil. Oil serves primarily as a source of energy and carbon precursors in germinating seed. Synthesis of storage lipids occurs in the seed and, thus, oil composition is genetically determined by the embryo, and relative weight of the embryo to endosperm and seed coat determines oil content. It is generally accepted that there is a negative relationship between protein and oil content. Oil and protein constituents are synthesized at different rates and times during oilseed development. Variation in nitrogen fertility during seed development and maturation affects the synthesis of fatty acids and, therefore, their final proportions in the oils of mature seeds. Since not only oil composition but oil content as well is affected by nitrogen fertility, this can affect oil utilization and the value of specific oilseed crops. While nitrogen-limiting situations generally reduce total oilseed production and, hence, oil yield per acre, there are few instances where the crop quality is actually reduced by inadequate nitrogen availability. 


\subsection{Sunflower}

Sunflower (Helianthus annuus L.) is capable of considerable translocation of nitrogen from leaves to maturing seeds (Cheng and Zubriski, 1978; Mathers and Stewart, 1982; Hocking and Steer, 1983). Numerous trials have been conducted on response to nitrogen fertility, but the response estimate proposed by Dahnke et al. (1981) seems to be rigorous enough to fit most other reports. It is based on the equation: nitrogen fertilizer applied $=0.05$ $\times$ Yield goal - Nitrate nitrogen in a $150-\mathrm{cm}$ soil sample. Higher levels of nitrogen fertility can affect seed quality by increasing protein and decreasing oil concentrations (Steer et al., 1984, 1986). The increase in yield response to nitrogen fertilizer, however, resulted in an overall increase in oil yield. Geleta et al. (1997) found both a significant decrease in oil content and return per acre as nitrogen rates increased from 40 to $115 \mathrm{~kg} / \mathrm{ha}$. They broke the 37 site years into three groups (high, medium, and low yielding) and found a similar response for all three groups. Besides nitrogen fertilizer effects on oil concentration, Steer and Seller (1990) found that the application of nitrogen fertilizer before floret initiation increased the concentrations of palmitic and linoleic acids, but decreased those of stearic and oleic acids. On the contrary, Bahl et al. (1997) found a decrease in oil content with additional nitrogen, but an increase in the ratio of oleic acid and linoleic acid. The discrepancy may have to do with nitrogen-phosphorus interactions, since the studies varied in their phosphorus treatments. This information may be helpful in managing mid-oleic sunflowers that are currently increasing in market share.

\subsection{Rapeseed}

Rapeseed (Brassica napus L.) also tends to have reduced oil content with high nitrogen fertility (Krogman and Hobbs, 1975; Holmes and Ainsley, 1979). As glucosinolates are synthesized from sulfur amino acids, glucosinolate content is affected by both nitrogen and sulfur availability and the nitrogen: sulfur ratio should be taken into account when assessing the effect of nitrogen on glucosinolate content. A plentiful supply of both elements can result in high levels of glucosinolates and, according to Grant and Bailey (1993), the optimal ratio of nitrogen to sulfur is 12 at flowering time. High glucosinolate content has been recorded after restricted nitrogen fertilizer application: the effect of nitrogen on seed glucosinolate content varied from one year (Bilsborrow et al., 1993). Forster (1978) found that in pot studies nitrogen rate lowered seed oil content and increasing potassium content, at the high nitrogen rate, increased oil content. He also found an increase in glucosinolate and protein content with increasing nitrogen rates.

A negative correlation between oil and protein content in the traditional determination of seed quality is well documented. High nitrogen applications reduce oil content and increase protein content. The economic value of the oil has led to reduced nitrogen usage and protein content of the meal has been decreasing. 


\subsection{Soybean and Peanuts}

Soybeans (Glycine max (L.) Merr.) and peanuts (Arachis hypogaea L.), both nodulating legumes, are still responsive under many conditions to increasing nitrogen levels in terms of yield. However, the oil content appears to be less negatively impacted by nitrogen rates (Bishnoi and Dutt, 1980; Pawar et al., 1982; Abdel-Wahab et al., 1988; Nagre et al., 1991). However, there are still several reports of decreasing oil concentration at higher nitrogen rates (Hassan et al., 1985; Jadhav et al., 1994). Ohyama et al. (1994) report on variation in amino acid ratios in soybeans under nitrogen limiting and adequate conditions, with aspartic acid being higher under the nitrogen limiting conditions.

\section{Root and Tuber Crops}

\subsection{Sugarbeet}

For thousands of years, sugar, as sucrose is commonly called, has been a valuable part of human diet. Sucrose is an important component or additive to a broad range of foods, beverages, and pharmaceuticals. Two-thirds of consumed sugar stems from sugarcane (Saccharum officinarum L.) and onethird of consumed sugar stems from sugarbeet (Beta vulgaris L.). Sugarcane is produced in tropical and subtropical climates, whereas sugarbeet is produced in temperate climates.

For the last 50 years, refined nitrogen nutrition has been a major focus of agronomic practices in growing sugarbeet. There are several reasons for this. Firstly, soil supply of mineral nitrogen forms is often not sufficient for optimal crop growth (biomass) and a producer has, through addition of nitrogen fertilizers, immediate control over the nitrogen economy of the crop; secondly, correct nitrogen nutrition is crucial for the quality of the crop; and thirdly, losses of nitrogen from cropping systems have been implicated in the contamination of surface and groundwater.

Once harvested, sugarbeet will undergo a series of processing steps until almost pure sugar ( $>99.9 \%$ sucrose) is obtained. Beets are stored for a period of up to several months. At the factory, beets are flurned, washed, and sliced in thin strips. Raw juice is obtained from these strips by counter-extraction (diffusion) with hot water. Raw juice is submitted to several purification and concentration processes. From concentrated juice sucrose is harvested, crystallized under vacuum, in several steps involving repeated dissolution of nonextractable sugars to gain as much sucrose as possible. In the end of these processes, there are basically three components left of the sugarbeet crop: sucrose, molasses, and beet pulp. Molasses is the syrup that contains all the components from which no more sugar can be extracted economically and beet pulp is the insoluble beet tissue left over from the process of counterextraction. Both, molasses and pulp are commonly sold as animal feed.

While adequate nitrogen supply to the crop must be insured to obtain optimal root yield, excessive nitrogen supply can have several detrimental effects on sugar-beet quality. Excessive nitrogen supply, especially late in the 
growing season, has in general two main effects on the quality of the harvested beets: (1) it decreases the concentration of sucrose in the beets; and (2) it increases the impurities of the juice from which sugar is extracted.

The decrease in sucrose concentration is mainly caused by dilution, that is, the roots retain more water, which in turn reduces the concentration of sucrose per unit fresh matter (Wieninger and Kubadinow, 1973). Abundant nitrogen supply also reduces the amount of marc (Wieninger and Kubadinow, 1973). Marc is the insoluble part of the sugarbeet root. It is the main component of beet pulp. As such, it is the second most valuable product of sugarbeet. A secondary component of the reduction of marc by oversupply of nitrogen, is that under such conditions sugarbeet roots tend to be heavier and contain relatively less marc (Beiss, 1988). Under high nitrogen supply, the physical strength of the beet tissue is lower (Bürcky et al., 1978; Drath et al., 1984). This is undesirable for two reasons. Firstly, lower tissue strength results in higher losses during harvesting and handling of beets due to breakage and associated losses by invasions of pathogen through wounds. Secondly, lower physical strength of the root tissue also causes problems during slicing of beets. Strips obtained from such roots often are not optimally conducive to sucrose extraction process.

Juice purity is reduced by excessive nitrogen through increases in alpha-amino-nitrogen (Wiklicky, 1971; Burba et al., 1984), invert sugars, lime salts (Reinefeld and Baumgarten, 1975), and raffinose (Burba and Nitzschke, 1980). Sugarbeets take up most of the nitrogen (150-170 kilogram of nitrogen per hectare) before row closure of the canopy. After row closure, they have only modest demand for additional nitrogen (about 1 kilogram of nitrogen per hectare per day). When nitrogen uptake exceeds demand, the concentration of nitrogenous impurities, especially alpha-amino acids, increases. At high levels, they hurt the crystallization process of sugar, thereby, rendering sugar extraction less efficient (Armstrong and Milford, 1985). Invert sugars (glucose and fructose) are obtained by acid or enzyme (invertase) hydrolysis of sucrose. High levels of invert sugars mean losses of sucrose. Additionally, high levels of invert sugars cause discoloration of white sucrose. Invert sugars are also the primary cause of increased lime salts (K, Na) (Oldfield et al., 1971). Lime salts in turn increase the amount of sucrose lost to molasses. High levels of raffinose can decrease the crystallization rate of sucrose and impair sucrose crystal morphology (Vaccari et al., 1986).

\subsection{Potatoes}

Many production variables influence the quality of potatoes (Solarium tuberosum L.) for processing into chips and fries, and for the count-carton fresh market (Pavlista, 1995). Besides fertilization, cultivar selection, seed quality, planting density, soil moisture (irrigation), timeliness of farming operations, crop rotations, vine desiccation, handling, and storage are controllable production variables that effect quality (Pavlista and Ojala, 1997). Processors require high quality for chips and fries with desirable color, flavor, texture, and 
appearance (Gould and Plimpton, 1985). Nitrogen fertilization has a key impact on potato quality for processing, as well as influencing potato size for the fresh market. Not only is tuber size affected by nitrogen but also starch content, estimated by specific gravity, and sugar content is greatly affected (Talbert and Smith, 1975; Salunkhe et al., 1991).

Soils used for potato production nearly always require nitrogen to be added for optimum yields and quality. Nitrogen is typically added at the beginning and the middle of the season. It is often applied before planting or during early vegetative stages of growth. Nitrogen may be additionally supplied through irrigation systems during early tuber growth. Petiole nitrate-nitrogen is often monitored during vine and early tuber growth, and guidelines are available for many cultivars. Adequate nitrogen will usually improve tuber quality, size, maturity, dry matter and sugar content (Table 3).

Tubers from plants with low nitrogen are usually small with low dry matter content and high reducing sugar levels (Iritani and Weller, 1980; Sowokinos and Preston, 1988). Excessive nitrogen delays tuber initiation, while promoting excessive vine growth. Too much nitrogen results in tubers with a lower dry matter content and immature skin prone to bruising and susceptibility to shatter bruise (Dean and Thornton, 1992). Proper nitrogen fertilization of potato crops is important to achieve optimum quality for processing.

Quality-processed potato chips and French fries can only be made from high-quality raw product. The major attributes important for potato chip and French fry processing include optimum size and shape, minimal external and internal defects, and desirable dry matter and sugar contents. These attributes determine finished product quality, for example, size or length, color, texture, uniformity, and desired appearance (Gould and Plimpton, 1985). Two key quality characteristics affected by nitrogen are specific gravity (dry matter content) and reducing sugar (glucose) content.

Table 3. Influence of nitrogen levels of potato crops on tuber quality.

\begin{tabular}{lll}
\hline Deficient & Adequate & Excess \\
\hline Very small tubers & Optimal-sized tubers & Slightly small tubers \\
High sugar levels & Low sugar levels & High sugar levels \\
Low dry matter & High dry matter & Medium dry matter* \\
Few useables & Most useable & Many useables \\
Over-mature tubers & Mature tubers & Immature tubers* \\
Disease susceptible & Disease resistant & Disease and bruise \\
& & susceptible \\
\hline
\end{tabular}

*Phosphorus fertilizer application will help to improve quality (e.g., skin maturity and dry matter content) of tubers at harvest when potato crops have excessive nitrogen fertility levels. 
Dry matter content varies from $15 \%$ to $24 \%$ between potato types and cultivars (Pavlista, 1997). Potatoes used for potato chips and French fries require a narrow range in dry matter content. Higher dry matter content (higher specific gravity) in raw product improves recovery rate during processing and directly influences texture and appearance, and indirectly influences the color of potato chips and French fries. Since specific gravity has a near-linear relation with dry matter and starch content in tubers, it is the common way for measuring these quality characters.

For potato chips, specific gravity is critical because it affects the thickness, color, crispness, oiliness, and the taste of the product. It also affects the recovery rate of chips from raw potato tubers. The preferred specific gravity for chipping potato tubers is between 1.090 and 1.099. Higher shear forces, resulting from high specific gravity, increase the mealiness and dryness giving the chip its characteristic "snap" or brittleness. The principle component of texture is starch content. The lower the specific gravity of the tuber, the more fragile is the final potato chips and the more likely they are to break. This breakage is called "hash" in packages.

For French fries, specific gravity has more influence on the quality of the finished fries and the production efficiency of the processing plant than any other single tuber quality. Specific gravity determines the French fry's texture, appearance, recovery rate, oil usage, and energy usage by the processing plant. Potatoes processed into French fries should be within a range of specific gravity, 1.080-1.089, to produce fries with excellent texture and appearance. High specific gravity does not guarantee the best texture, but low specific gravity does guarantee that the product will have an inferior consistency or texture.

North American consumers prefer potato chips and French fries to have a uniform light color. Light brown, or darker color, chips are usually not well received. Finished product color in potato chip and French fry processing is determined particularly by glucose content. For low glucose content, proper maturation before harvest is essential for allowing reducing sugars to reach low levels in tubers. During frying, the critical chemical reactions that cause darkening of potato chips and French fries are nonenzymatic browning (Maillard reaction) during frying.

The brown color caused by the Maillard reaction is due to polymerized cyclamen. Glucose in potato tissues reacts with asparagine, an amino acid, to produce cyclamen which then polymerizes during frying to form a discoloration. Asparagine is usually present at a sufficiently high concentration for this reaction, so, glucose is the limiting substrate. Glucose levels higher than about $0.35 \mathrm{mg} / \mathrm{g}$ of fresh potato will result in brown product.

\section{Forages}

Forages are an important component of agricultural systems. In the United States more than $50 \%$ of agricultural land is kept in grassland pasture 
and cropland used only for pasture (USDA, 1992). The forage resource is the backbone of animal meat production.

Nitrogen is the most limiting factor for grassland productivity. Hence, application of nitrogen fertilizers profoundly affects grassland systems in many ways. At low rates, nitrogen fertilization increases forage yield with little effect on forage nitrogen. It stimulates tiller development, increases leaf size, and lengthens the period of green leaves (Rhykerd and Noller, 1974). At a higher level of nitrogen fertilization. yield and nitrogen concentration in the forage are increased. Increased water concentration and decreased soluble carbohydrates are commonly observed after nitrogen fertilization of grasses (Messman et al., 1991; Brink and Fairbrother, 1992).

Most of the nitrogen taken up by the forages is incorporated into protein. However, $10-30 \%$ of the absorbed nitrogen exists in the plant as nonprotein nitrogen, mainly amino acids, nitrate, and secondary plant metaholites (Dougherty and Rhykerd, 1985). Accumulation of nitrates within forages can he a problem under conditions of high nitrogen supply and impaired photosynthesis, for example, low level of solar radiation or drought stress (Stritzke and McMurphy. 1982). Animal health problems are a consequence when nitrate is reduced to nitrite in the rumen and absorbed in the bloodstream. A wide range in critical forage nitrate concentration has been observed. Dougherty and Rhykerd (1985) reported that a nitrate concentration as low as $0.1 \%$ can cause problems, whereas Kemp and Geuring (1978) observed problems only at the much higher concentration of $6 \%$. Low levels of soluble carbohydrates may cause problems with silage fermentation, resulting in poor silage quality.

Nitrogen application will also increase the concentration of total organic acids and alkaloids in forage. Wedin (1974) and Odom et al. (1980) suggested that increased alkaloid concentration in reed canary grass (Phalaris arundinacea L.) and tall fescue (Festuca arundinacea Scherb.) may be responsible for lower forage palatability, resulting in lower forage intake. Bush et al. (1979) observed that accumulation of perloline in tall fescue was a contributing factor to summer toxicosis syndrome.

Nitrogen fertilization also has an impact on mineral composition of the forage. If nitrogen is supplied in the ammonium form. uptake of cations such as calcium, potassium, and magnesium is reduced (George and Thill, 1979). By lowering magnesium concentration, ammonium fertilization may induce grass tetany. Other effects of nitrogen fertilization on mineral composition of forages are inconsistent. Whitehead et al. (1986) found lower concentrations of macroand micronutrients. caused mainly by dilution, whereas Reid and Jung (1974) reported little effect of nitrogen fertilization on mineral composition of forage.

Nitrogen fertilization of forages often had little impact on forage digestibility. Van Soest (1982) reported that as nitrogen fertilization increases lignin production, digestibility may be reduced. Others (Messman et al., 1991: Puoli et al., 1991) found that the rate of neutral detergent fiber digestion and with it animal feed intake was increased upon nitrogen fertilization. Nitrogen fertilization of forages was more likely to increase digestibility of warm-season 
grasses because of their lower nitrogen content as compared to cool-season grasses (George and Hall, 1983). The main beneficial effect of nitrogen fertilization of forages, on meat production per unit land, increases in yield resulting in increased carrying capacity (Wedin, 1974). In warm-season grasses, many studies found that increased nitrogen fertilization caused higher beef gains in kg/ha (Rhem et al., 1975; Perry and Baltensperger, 1979).

\section{References}

Abdel-Wahab, A.M., G.M. Yakout, A.A. Mohamed, and H.M. Abd-El-Motaleb. 1988. Effect of different levels of nitrogen, phosphorus, potassium and calcium on peanut. Egyptian J. Agron. 11:79-92.

Alexander, D.E. 1988. Breeding special nutritional and industrial types, pp. 869-880. In C.F. Sprague and J.W. Dudley (eds) Corn and corn improvement, 3rd edition, American Society of Agronomy, Madison, WI.

Altman, D.W., W.L. McCuistion, and W.E. Kronstad. 1983. Grain protein percentage, kernel hardness, and grain yield of winter wheat with foliar applied urea. Agron. J. 75: 87-91.

Anderson, E.L., E.J. Kamprath, and R.H. Moll. 1984. Nitrogen fertility effects on accumulation, remobilization, and partitioning of $\mathrm{N}$ and dry matter in corn genotypes differing in prolificacy. Agron. J. 76: 397-404.

Armstrong, M. and G. Milford. 1985. The nitrogen nutrition of sugar beet: the background to the requirement of sugar yield and amino-N accumulation. British Sugar Beet Rev. 53(4): 42-44.

Bahl, G.S., N.S. Pasricha, and K.L. Ahuja. 1997. Effect of fertilizer nitrogen and phosphorus on the grain yield, nutrient uptake and oil quality of sunflower. J. Indian Soc. Soil Sci. 45: 292-296.

Bauer, P.J. and P.R. Carter. 1986. Effect of seeding date, plant density, moisture availability, and soil nitrogen fertility on maize kernel breakage susceptibility. Crop Sci. 17: 362-366.

Beiss, U. 1988. Influence of some factors on marc content of sugar beet. Zuckerindustrie 113:1041-1048.

Benzian, B. and P. Lane. 1979. Some relationships between grain yield and grain protein of wheat experiments in south-east England and comparisons with such relationships elsewhere. J. Sci. Food Agric. 30: 59-70.

Bhatia, C.R. and R. Rabson. 1976. Bioenergetic considerations in cereal breeding for protein improvement. Science 194: 1418-1421.

Bhatia, C.R. and R. Rabson. 1987. Relationship of grain yield and nutritional quality, pp. 11-44. In R.A. Olson and K.I. Frey (eds) Nutritional quality of cereal grains: Genetics and agronomic management, American Society of Agronomy, Madison, WI.

Bilsborrow, P.E., E.J. Evans, and F.J. Zhao. 1993. The influence of spring nitrogen on yield, yield components and glucosinolate content of autumn-sown oilseed rape (Brassica napus). ]. Agric. Sci. 120: 219-224.

Bishnoi, K.C. and R. Dutt. 1980. Effect ofrhizobium isolates inoculation methods and nitrogen levels on nodulation and quality of soybean. Indian J. Agron. 25: $544-545$. 
Blumenthal, J.M., D.D. Baltensperger, D.R. Shelton, L.A. Nelson, G.D. Binford, and S. Geleta. 2000. Nitrogen and variety effects in winter wheat, Abstracts of the Third International Crop Science Congress, Hamburg, Germany.

Breteler, H. 1976. Nitrogen fertilisation, yield and protein quality of a normal and high-lysine maize variety. J. Sci. Food Agric. 27: 978-982.

Brink, G.B. and T.E. Fairbrother. 1992. Bermudagrass-subterranean clover response to nitrogen application. J. Prod. Agric. 5: 591-595.

Bullock, D.G., P.L. Raymer, and S. Savage. 1989. Variation of protein and fat concentration among commercial corn hybrids grown in the southeastern USA. J. Prod. Agric. 12: 157-160.

Burba, M. and U. Nitzschke. 1980. Nachweis und eigenschaften der saccharose spaltenden enzyme der zuckerrübe. Zuckerindustrie 105: 149-155.

Burba, M., U. Nitzschke, and R. Ritterbusch. 1984. Die N-assimilation der pflanze unter besonderer berücksichtigung der zuckerrüibe. Zuckerindustrie 109: 613-628.

Bush, L.P., J.A. Boling, and S. Yates. 1979. Animal disorders, pp. 247-292. In R.C. Buckner, L.P. Bush (eds) Tall fescue, Agron Monogr 20. American Society of Agronomy, Madison, WI.

Bürcky, K., U. Beiss, C. Winner, L. Drath, and H. Schiweck. 1978. Versuch zur bedeutung des nahrstoffangebotes fur die qualitat der zuckerrübe. II: Stickstoff und kalium. Zuckerindustrie 103: 190-200.

Byers, M. and J. Bolton. 1979. Effects of nitrogen and sulfur fertilizers on yield, N and S content, and amino acid composition of the grain of spring wheat. J. Sci. Food Agric. 30: 250-261.

Cagampang, G.B., L.J. Cruz, S.G. Espiritu, R.G. Santiago, and B.O. Juliano. 1966. Studiens on the extraction and composition of rice proteins. Cereal Chem. 43: 145-155.

Cheng, S.F. and J.C. Zubriski. 1978. Effects of nitrogen fertilizer on production of irrigated sunflower, plant uptake of nitrogen, and on water use, pp. 400-409. In Proc. 8th Int. Sunflower Conf., Minneapolis, MN 23-27 July. International Sunflower Association, Paris, France.

Christensen, N.W. and R.J. Killhorn. 1981. Wheat and barley growth and N fertilizer utilization under sprinkler irrigation. Agron. J. 74: 840-844.

Cromwell, G.L., M.J. Bitzer, T.S. Stahly, and T.H. Johnson. 1983. Effects of soil nitrogen fertility on the protein and lysine content and nutritional value of normal and opaque-2 corn. J. Anim. Sci. 57: 1345-1351.

Dahnke, W.C., J.C. Zubriski, and E.H. Vasey. 1981. Fertilizing sunflowers, North Dakota State Univ. Coop. Ext. Serv. Circ. SF-713, Fargo, ND.

De Datta, S.K., W.N. Obcemea, and R.K. Jana. 1972. Protein content of rice grain as affected by nitrogen fertilizer and some triazines and substituted ureas. Agron. J. 64: 785-788.

Dean, B.B. and R.E. Thomton. 1992. The specific gravity of potatoes, Washington State Univ. Cooperative Extension Bulletin \#1541, Pullman, WA.

Dougherty, C.T. and C.L. Rhykerd. 1985. The role of nitrogen in forage-animal production, pp. 318-326. In M.E. Health, R.F. Barnes, and D.S. Metcalfe (eds) Forages: The science of grassland agriculture, 4th edition, Iowa State Univ. Press, Ames 10. 
Drath, L., R. Strauss, and H. Schiweck. 1984. Untersuchungen über die mechanischen eigenschaften von zuckerrüben. II: Einflussfaktoren auf die bruchfestigkeit von rüben. Zuckerindustrie 109: 993-1007.

Earle, F.R. 1977. Protein and oil in corn: Variation by crop years from 1907 to 1972. Cereal Chem. 54: 70-79.

Finney, K.R, W.T. Yamazaki, V.L. Youngs, and G.L. Rubenthaler. 1987. Quality of hard, soft, and durum wheats, pp. 677-748. In E.G. Heyne (ed.) Wheat and wheat improvement, 2nd edition, American Society of Agronomy, Madison, WI.

Forster, H. 1978. Influence of $\mathrm{N}$ and $\mathrm{K}$ fertilizers on the quality and yield of oil from old and new varieties of rapeseed (Brassica napus ssp. oleifera), pp. 305-310. In Fertilizer use and production of carbohydrates and lipids.

Fowler, D.B. and L.A. de la Roche. 1984. Winter wheat production on the north central Canadian prairies: protein quality classes. Crop Sci. 24: 873-876.

Frey, K.J. 1951. The inter-relationships of protein and amino acids in corn. Cereal Chem. 28: 123-132.

Frey, K.J. 1977. Proteins of oats. Zeitschrift fur Pflanzenzüchtung 78: 185-215.

Frey, K.J., B. Brimhall, and G.F. Sprague. 1949. The effects of selection upon protein quality in the corn kernel. Agron. J. 41: 399.

Gallagher, P.J., L.S. Murphy, C.L. Harms, and W.A. Moore. 1973. Comparisons of effects of nitrogen carriers, rates, and time of application on yield and quality of winter wheat. Kansas Fert. Res. Rep. Prog. 202: 59-60.

Geleta, S., D.D. Baltensperger, G.D. Binford, and J.F. Miller. 1997. Sunflower response to nitrogen and phosphorus in wheat-fallow cropping systems. J. Prod. Agric. 10: 466-472.

George, J.R. and K.E. Hall. 1983. Herbage quality of three warm-season grasses with nitrogen fertilization. Iowa State J. Res. 58: 247-259.

George, J.R. and J.L. Thill. 1979. Cation concentration of N- and K-fertilized smooth brome-grass during the spring grass tetany season. Agron. J. 71: 431-436.

Goos, R.J., D.G. Westfall, A.E. Ludwick, and J.E. Goris. 1982. Grain protein content as an indicator of N sufficiency for winter wheat. Agron. J. 74: 130-133.

Goos, R.J. 1984. Post-harvest evaluation of nitrogen management-a new approach for "selling" soil testing to wheat farmers. J. Agron. Educ. 13: 103-106.

Gould, W.A. and S. Plimpton. 1985. Quality evaluation of potato cultivars for processing, North Central Regional Research Publication \#305.

Grant, C.A. and L.D. Bailey. 1993. Fertility management in canola production. Can. J. Plant Sci. 73: 651-670.

Hamaker, B.R. 1994. The influence of rice protein on rice quality, pp. 177-193. In W.E. Marshall and J.I. Wadeworth (eds) Rice science and technology, Marcel Dekker, New York.

Hancock, J.D., E.R. Peo Jr., A.J. Lewis, K.R. Kniep, and S.C. Mason. 1988. Effects of irrigation and nitrogen fertilization of normal and high lysine corn on protein utilization by the growing rat. Nutr. Rep. Intern. 38: 413^22.

Hassan, R.A., E.M. El-Hadidi, and S.M. Hassan. 1985. Oil, protein, amino acid content and yield of soybean seeds as affected by $\mathrm{N}$ and $\mathrm{P}$ fertilization. J. Agric. Sci. 10(1): 53-57. 
Hocking, P.J. and B.T. Steer. 1983. Uptake and partitioning of selected mineral elements in sunflower (Helianthus annum L.) during growth. Field Crops Res. 6: 93-107.

Holmes, M.R.J. and A.M. Ainsley. 1979. Nitrogen top-dressing requirements of winter oilseed rape. J. Sci. Food Agric. 30: 119-128.

Iritani, W.M. and L.D. Weller. 1980. Sugar development in potatoes, Washington State Univ. Cooperative Extension Bulletin \#0717, Pullman, WA.

Jadhav, P.J., A.S. Jadhav, and S.M. Bachchhav. 1994. Effects of N, row spacing and plant densities on the yield and quality of soybean. J. Maharashtra Agric. Univ. 19: 75-77.

Jellum, M.D., EC. Boswell, and C.T. Young. 1973. Nitrogen and boron effects on protein and oil of corn grain. Agron. J. 65: 330-331.

Juliano, B.O. 1993. Rice in human nutrition. FAO Food Nutr. Ser. No. 26, International Rice Research Institute, Manila, Philippines.

Kemp, A. and J.H. Geurkig. 1978. Grassland farming and minerals in cattle. Netherlands J. Agric. Sci. 26: 161-169.

Kies, C. and H.M. Fox. 1974. Triticale and human nutrition, pp. 202-211. In C.C. Tsen (ed.) Triticale: first man-made cereal, American Association of Cereal Chemists, St. Paul, MN.

Kniep, K.R. and S.C. Mason. 1989. Kernel breakage and density of normal and opaque-2 maize grain as influenced by irrigation and nitrogen. Crop Sci. 29: 158-163.

Kniep, K.R. and S.C. Mason. 1991. Lysine and protein content of normal and opaque2 maize grain as influenced by irrigation and nitrogen. Crop Sci. 31: 177-181.

Krogman, K.K. and E.H. Hobbs. 1975. Yield and morphological response of rape (Brassica campestris L.Cv. Span) to irrigation and fertilizer treatments. Can. J. Plant Sci. 55: 903-909.

MacGregor, J.M., L.T. Taskovitch, and W.P. Martin. 1961. Effect of nitrogen fertilizer and soil type on the amino acid content of corn grain. Agron. J. 53: 211-214.

Mathers, A.C. and B.A. Stewart. 1982. Sunflower nutrient uptake, growth, and yield as affected by nitrogen or manure, and plant population. Agron. J. 74: 911-915.

McDermitt, D.K. and R.S. Loomis. 1981. Elemental composition of biomass and its relation to energy content, growth efficiency, and growth yield. Ann. Bot. 48: 275-290.

Mertz, E.T., L.S. Bates, and O.E. Nelson. 1964. Mutant gene that changes protein composition and increases lysine content of maize endosperm. Science 145: 279.

Messman, M.A., W.P. Weiss, and D.O. Erickson. 1991. Effects of nitrogen fertilization and maturity of bromegrass on in situ ruminal digestion kinetics of fiber. J. Anim. Sci. 69: 1151-1161.

Nagre, K.T., S.B. Deshmukh, P.D. Bhalerao, and P.V. Thorve. 1991. Effect of sowing dates and fertilizers on growth, yield and quality of soybean varieties. PKV Res. J. 15: 82-84.

Nangju, D. and S.K. De Datta. 1970. Effect of time of harvest and nitrogen level on yield and grain breakage in transplanted rice. Agron. J. 62: 468-474.

Odom, O.J., R.L. Haaland, C.S. Hoveland, and W.B. Anthony. 1980. Forage quality response of tall fescue, orchardgrass, and phalaris to soil fertility level. Agron. J. 72: 401-402. 
Ohyama, T., N. Ohtake, T. Nishiwaki, K. Mizukoshi, R. Minagawa, K. Kobayashi, T. Chinushi, and Y. Takahashi. 1994. Effect of $\mathrm{N}$ fertilization on seed quality and xylem transport forms in nodulating and non-nodulating soybean isolines. Bui. Fac. Agric. Nügata Univ. 46: 57-70.

Oikeh, S.O., J.G. Kling, and A.E. Okoruwa. 1998. Nitrogen management effects on maize grain quality in the West Africa moist savanna. Crop Sci. 38: 1056-1061.

Oldfield, J.F.T., J.V. Dutton, and H.J. Teague. 1971. The significance of invert and gum formation in deteriorated beet. Internal. Sugar J. 73. 3-8, 35-40, 66-68.

Olsen, R.A., K.D. Frank, E.J. Deibert, A.F. Dreier, D.H. Sander, and V.A. Johnson. 1976. Impact of residual mineral $\mathrm{N}$ in soil on grain protein yields of winter wheat and corn. Agron.J. 68: 769-772.

Paulsen, M.R. and L.D. Hill. 1985. Corn quality factors affecting dry milling performance. J. Agric. Eng. Res. 31: 255-263.

Pavlista, A.D. 1995. Potato production stages: Scheduling key practices, Univ. Nebraska Cooperative Extension Circular \# 95-1249, Lincoln, NE.

Pavlista, A.D. 1997. Potato types, characteristics and their uses. Amer. Biol. Teacher 59: 26-29.

Pavlista, A.D. and J.C. Ojala. 1997. Potatoes: Chip and fry processing. In Smith, Cash, Nip, and Hui (eds) Processing vegetables: Science and technology, Technomics Publ. Co. Inc., Lancaster, PA.

Pawar, V.P, N.T. Sarnaik, and V.D. Sondge. 1982. Effect of nitrogen and phosphate on yield and quality of soybean (Glycine max (L.) Merrill) varieties. J. Maharashtra Agric. Univ. 7:90.

Penning de Vries, F.W.T., A.H.M. Brunsting, and H.H. van Laar. 1974. Products, requirements and efficiency of biosynthesis: A quantitative approach. J. Theor. Biol. 45: 339-377.

Perez, C.M., B. Juliano, S. Liboon, J.M. Alcantara, Jovencio, and K.G. Cassman. 1996. Effects of late nitrogen fertilizer application on head rice yield, protein content, and grain quality of rice. Cereal Chem. 73: 556-560.

Perry, W.P. 1988. Corn as a livestock feed, pp. 941-963. In C.E Sprague and J.W. Dudley (eds) Corn and corn improvement, 3rd edition, American Society of Agronomy, Madison, WI.

Perry Jr., L.J. and D.D. Baltensperger. 1979. Leaf and stem yields and forage quality of three N-fertilized warm-season grasses. Agron. J. 71: 355-358.

Pierre, W.H., L. Dumenil, V.D. Jolley, J.R. Webb, and W.D. Shrader. 1977. Relationship of corn yield, expressed as a percentage of maximum and the $\mathrm{N}$ percentage in grain: I. Various N-rate experiments. Agron. J. 69: 215-220.

Poulsson, E. 1973. Amino acid analyses of wheat grain and gain fractions. Sci. Rep. Agric. Univ. Norway. 52: 1-18.

Puoli, J.R., G.A. Jung, and R.L. Reid. 1991. Effects of nitrogen and sulfur on digestion and nutritive quality of warm-season grass hays for cattle and sheep. J. Anim. Sci. 69: 843-852.

Reid, R.L. and G.A. Jung. 1974. Effects of elements other than nitrogen on the nutritive value of forage, pp. 395-435. In D.A. Mays (ed.) Forage fertilization, American Society of Agronomy, Madison, WI.

Reinefeld, E. and G. Baumgarten. 1975. Verarbeittungseigenschaften der zuckerrübe in abhängigkeit vom stickstoffangebot. Zucker 28: 61-65. 
Rendig, V.V. and F.E. Broadbent. 1979. Proteins and amino acids in grain of maize grown with various levels of N. Agron. J. 71: 509-512.

Rhem, G.W., J.T. Nichols, R.C. Sorensen, and W.J. Moline. 1975. Yield and botanical composition of and irrigated grass-legume pasture as influenced by fertilization. Agron. J. 67: 64-68.

Rhykerd, C.L. and C.H. Noller. 1974. The role of nitrogen in forage production, pp. 416-424. In D.A. Mays (ed.) Forage fertilization, American Society of Agronomy, Madison, WI.

Sabata, R.J. and S.C. Mason. 1992. Corn hybrid interactions with soil nitrogen level and water regime. J. Prod. Agric. 5: 137-142.

Salunkhe, D.K., S.S. Kadam, and S.J. Jadhav. 1991. Potato: Production, processing, and products, CRC Press.

Sander, D.H., W.H. Allaway, and R.A. Olson. 1987. Modification of nutritional quality by environment and production practices, pp. 45-82. In R.A. Olson and K.I. Frey (eds) Nutritional quality of cereal grains: Genetics and agronomic management, American Society of Agronomy, Madison, WI.

Shumway, C.R., J.T. Cothren, S.O. Sema-Saldivar, and L.W. Rooney. 1992. Planting date and moisture effects on yield, quality and alkaline-processing characteristics of food-grade maize. Agron. J. 32: 1265-1269.

Simmonds, D.H. 1978. Structure, composition, and biochemistry of cereal grains, pp. 105-137. In Y. Pomeranz (ed.) Cereals '78: better nutrition for the world's millions, American Association of Cereal Chemists, St. Paul, MN.

Sowokinos, J.R. and D.A. Preston. 1988. Maintenance of potato processing quality by chemical maturity monitoring (CMM), Minnesota Agricultural Experiment Station Bulletin \#586-1988, St. Paul, MN.

Steer, B.T., P.D. Coaldrake, C.J. Pearson, and C.P. Canty. 1986. Effects of nitrogen supply and population density on plant development and yield components of irrigated sunflower (Helianthus annuus L.). Field Crops Res. 13: 99-115.

Steer, B.T., P.J. Hocking, A.A. Kortt, and C.M. Roxburgh. 1984. Nitrogen nutrition of sunflower (Helianthus annuus L.): Yield components, the timing of their establishment and seed characteristics in response to nitrogen supply. Field Crops Res. 9: 219-236.

Steer, B.T. and F.J. Seller. 1990. Changes in fatty acid composition of sunflower (Helianthus annuus) seeds in response to time of nitrogen application, supply rates and defoliation. J. Sci.FoodAgric.51: 11-26.

Stritzke, J.F. and W.E. McMurphy. 1982. Shade and N effects on tall fescue production and quality. Agron. J. 74: 5-8.

Talbert, W.F. and O. Smith. 1975. Potato processing, AVI Publications Co.

Timms, M.F, R.C. Bottomley, J.R.S. Ellis, and J.D. Schofield. 1981. The baking quality and protein characteristics of a winter wheat grown at different levels of nitrogen fertilization. J. Sci. Food Agric. 32: 684-698.

Tsai, C.Y., H.L. Warren, D.M. Huber, and R.A. Bressan. 1983. Interactions between the kernel $\mathrm{N}$ sink, grain yield and protein nutritional quality of maize. J. Sci. Food Agric. 34: 255-263.

Tsai, C.Y, I. Dweikat, D.M. Huber, and H.L. Warren. 1992. Interrelationship of nitrogen nutrition with maize (Zea mays) grain yield, nitrogen use efficiency and grain quality. J. Sci. Food Agric. 58: 1-8. 
Ulmer, R.L. 1973. Relationships of endosperm protein fractions from normal and high protein wheats to protein content, lysine content, quality, and nitrogen fertilization. Ph.D. Dissertation. University of Nebraska, Lincoln, NE (Diss. Abstr. 34:1835B).

USDA. 1992. Agricultural statistics, US Gov. Print. Off., Washington, DC.

Vaccari, G., G. Mantovani, G. Squaldino, D. Aquilano, and M. Rubbo. 1986. The raffinose effect on sucrose morphology and kinetics. Sugar Tech. Rev. 13: 133-178.

Van Soest, P.J. 1982. Nutritional ecology of the ruminants, Oregon O. and B. Books, Corvallis, OR.

Vasal, S.K., E. Villegas, M. Bjarnason, B. Gelaw, and P. Goertz. 1980. Genetic modifers and breeding strategies in developing hard endosperm opaque-2 materials, pp. 37-71. In W.G. Pollmer and R.H. Phipps (eds) Improvement of quality traits for grain and silage use, Martinus Nijhoff Publishers, The Hague, Netherlands.

Vogel, K.P, P.J. Mattern, and G.W. Lenser. 1976. Modified milling procedure for separating endosperm and nonendosperm of wheat kernel for protein and lysine analysis. Agron. J. 68: 686-690.

Watson, S.A. 1987. Measurement and maintenance of quality, pp. 125-183. In S.A. Watson and P.E. Ramstad (eds) Corn: Chemistry and technology, American Association of Cereal Chemists, St. Paul, MN.

Wedin, W.F. 1974. Fertilization of cool-season grasses, pp. 95-118. In D.A. Mays (ed.) Forage fertilization, American Society of Agronomy, Madison, WI.

Welch, L.F. 1969. Effect of N, P, and K on the percent and yield of oil in corn. Agron. J. 61: 890-891.

Whitehead, D.C., K.M. Goulden, and R.D. Hartley. 1986. Fractions of nitrogen, sulphur, phosphorus, calcium, and magnesium in the herbage of perennial ryegrass as influenced by fertilizer nitrogen. Anim. Feed Sci. Tech. 14: 231-242.

Wieninger, L. and N. Kubadinow. 1973. Die stickstoffdüngung und ihre auswirkung auftechnologische qualitätsemerkmale der zuckerrübe. Zucker 26: 65-70.

Wiklicky, L. 1971. The processing quality of sugar beet. Zucker 21: 667-672.

Wrigley, C.W, D.L. Ducros, M.J. Archer, P.G. Downie, and C.M. Roxburgh. 1980. The sulfur content of wheat endosperm and its relevance to grain quality. Aust. J. Plant Physiol. 7:755-766. 